\title{
Individual Differences in Risk-Taking Preference of Undergraduate Students*
}

\author{
Elif Aysimi Duman**
}

Boğaziçi University

\begin{abstract}
Risk-taking preference is an important contributor to undergraduates' decisions and behavior. This study aims to explore the associations between risk-taking preference and demographic factors and psychological traits. Undergraduates from Bogazici University ( $\mathrm{N}=177,42 \%$ female) completed questionnaires during a lab session. Risk-taking preference was measured by a well-established general risk question. The results showed that individuals who are older, male, and have higher income exhibit higher risk-taking preference. Furthermore, those with higher extraversion, agreeableness, openness and self-esteem, and with lower neuroticism and trait anxiety, had higher risk-taking preference. Gender differences among these associations and implications for students' behavior is discussed.
\end{abstract}

Keywords: Risk-taking, individual differences, personality, gender, undergraduate students JEL Classification: D0, D81, C91, J10

\section{Üniversite Öğrencilerinin Risk Alma Tercihinde Bireysel Farklılıklar}

\section{Özet}

Risk alma tercihi lisans öğrencilerinin kararlarını ve davranışlarını önemli derecede etkiler. Bu çalışmanın amacı, risk alma tercihiyle demografik faktörlerin ve psikolojik özelliklerin arasındaki ilişkileri incelemektir. Boğaziçi Üniversitesi'nden lisans öğrencileri ( $N=177, \% 042$ kadın) bir laboratuvar seansında ölçekler doldurmuştur. Risk alma tercihi iyi bilinen bir genel risk sorusuyla ölçülmüştür. Sonuçlara göre, daha yaşlı, erkek ve yüksek gelirli bireylerde risk alma tercihi daha yüksek çıkmıştır. Ayrıca, yüksek dışadönüklük, uyumluluk, açıklık ve benlik saygısı ve düşük duygusal denge ve sürekli kaygı da yüksek risk alma tercihiyle ilişkili bulunmuştur. Bu ilişkilerdeki cinsiyet farklılıkları ve bunların öğrencilerin davranışlarına yansımaları tartışılmıştır.

Anahtar Kelimeler: Risk alma, bireysel farklılıklar, kişilik, cinsiyet, lisans öğrencileri

JEL Sinıflandırması: D0, D81, C91, J10

\footnotetext{
* I thank Drs. Tolga Umut Kuzubas and Mehmet Yigit Gurdal for valuable discussions on measurement of risk-taking, and all Psychoepigenetics Lab members for assistance during data collection and processing. This study was funded by Bogazici University Research Foundation BAP Start Up Grant \#8249 and TUBITAK Career Development Grant \#115S532 awarded to EAD.

${ }^{* *}$ Elif Aysimi Duman, Assistant Professor. Department of Psychology \& Center for Life Sciences and Technologies, Bogazici University. Bogazici University South Campus, Sloane Hall, Bebek 34342 Istanbul, Turkey. E-mail: elif.duman@boun.edu.tr . Phone: +902123596554. ORCID ID: 0000-0003-0973-6869
} 


\section{Introduction}

\section{Background}

$\mathrm{R}$

isk-taking preference influences most of our daily decisions. However, both the varieties in its measurement and the influence of relevant individual differences render understanding individuals' risk-taking preference challenging. In order to measure risktaking preference, various studies have been conducted utilizing different approaches, from selfreports to behavioral paradigms, and these suggest that risk-taking preference has both general and domain-specific components. While there may be domain-specific components across the behavioral tasks used, these studies have proposed that a general component exists that preserves its stability over time, particularly when risk-taking preference is measured by self-reports (Dohmen et al., 2011; Frey et al., 2017). Comparing multiple measures, Dohmen et al. (2011) suggested that the general component of risk-taking preference is best measured by asking individuals to rate their risk-taking preference (0: not at all willing to 10: very willing), calling this "the general risk question" (p. 524). Compared to behavioral tasks, Gurdal et al. (2017) demonstrated that individuals' real-life choices of risk-taking are best predicted by this general risk question. Furthermore, this type of a risk-taking preference measure was proposed to exhibit similar psychometric properties to psychological traits, such as personality traits (Mata et al., 2018). Psychological traits encompass a wide range of emotions and behaviors that are influenced both by genetic and psychosocial factors (Duman \& Canli, 2010). Therefore, similar to risk-taking preference, these traits also have stable and dynamic properties and are influenced by a combination of demographic, genetic and psychosocial factors (Duman \& Canli, 2010; Figner \& Weber, 2011; Kuhnen \& Chiao, 2009; Schildberg-Hörisch, 2018). This study investigates how the general construct of risk-taking preference is related to individual demographic factors and psychological traits in undergraduate students. Given that the period of university education as an important neurodevelopmental, psychosocial and socioeconomic transition to adulthood, together with reports of increased instances of risky behavior during this time (reviewed in Pharo et al., 2011), investigating these relationships in undergraduate populations is important for identifying risk and resilience factors contributing to their behavior and health.

Among the demographic factors, there are conflicting findings in terms of the influence of age, mostly due to the cross-sectional nature of the studies, as well as the measurement of risktaking preference. Considering Dohmen's general risk question, Mamerow et al. (2016) reported lower risk-taking with increased age in a large sample of participants from age 18 to 90 . This pattern of reduced risk-taking is replicated in studies with a wide range of age. However, in younger populations, such as in adolescents and young adults, general risk-taking increases with age and the relationship may become more complicated, with additional influences of birth cohort effects and being alone or among peers (Jianakoplos \& Bernasek, 2006; Josef et al., 2016; Gardner et al., 2005). The findings are more consistent for gender, with studies reporting less risk-taking in women compared to men across different risk-taking paradigms (Byrnes et al., 1999; Croson \& Gneezy, 2009; Koyluoglu et al., 2019). However, it has been found that the gender gap may differ depending on developmental period and the domain of risk-taking (Byrnes et al, 1999). Socioeconomic status (SES), measured through income, education, occupation, social status and related factors, is another important contributor to individual differences in risk-taking. Research suggests increased risk-taking with increased parameters of SES, which may be moderated by age, 
stressful life experiences, and the nature of the risk-taking tasks utilized (Grable, 2000; Schurer, 2015).

Apart from demographic factors, previous research also investigated the effect of psychosocial factors on risk-taking (Demaree et al., 2008; Figner et al., 2011). While some studies investigated the role of psychosocial factors, such as social support and experiences of stressful life events, the majority of studies in the field of economics focused on the role of psychological traits. In terms of self-reported risk-taking preference, many studies indicated associations with the Big Five personality traits. Among these traits are neuroticism, extraversion, openness, agreeableness and conscientiousness (Costa \& McCrae, 2008; John et al., 1991) and they are shown to be associated with different domains of risk-taking behavior in different populations (e.g. students, investors). Although higher risk-taking is commonly associated with higher extraversion and openness to experience, and with lower neuroticism, agreeableness, and conscientiousness, the findings of these studies differ by measurement of risk and demographic characteristics (i.e. age, gender, SES) of the participants (e.g. Hitay \& Anbar, 2020; Kalabalik \& Aren, 2018; Koyluoglu et al., 2019; Nicholson et al., 2005; Oehler \& Wedlich, 2018). In addition to the Big Five personality traits, other psychological traits, such as trait anxiety, self-esteem and life satisfaction were also reported to influence risk-taking. Trait anxiety is typically associated with enhanced sensitivity to threat and risk aversion, and studies related to risk-taking have so far generally considered the role of this trait in clinical populations, such as those with generalized anxiety disorder (Charpentier et al., 2017; Giorgetta et al., 2012; but see Howlett \& Paulus, 2017). Fewer studies considered the relationships between risk-taking, self-esteem, and life satisfaction, and they particularly focused on adolescents and young adults' risky behavior. For instance, higher self-esteem (Cakar \& Tagay, 2017; Wild et al., 2008) and life satisfaction (MacDonald et al., 2005; Savi-Cakar et al., 2015; Valois et al., 2002) in adolescents were associated with less risky behavior. However, more studies are needed to examine whether similar associations are observed for differences in risk-taking preference and in other age groups.

Among these demographic and psychological traits influencing individual differences in risk-taking preference, an important contributor is gender, which has complex relationships with each of these factors. For instance, in terms of personality traits, women are consistently reported to show higher neuroticism, agreeableness and trait anxiety compared to men. On the other hand, men are generally reported to have higher extraversion, self-esteem and life satisfaction compared to women (e.g. Costa et al., 2001; Weisberg et al., 2011; Wild et al., 2008). Similarly, depending on the gender and social norms of a population, women's risk-taking may be influenced by different parameters of SES, such as income, education, living conditions, and occupation (Grable, 2000; Josephs et al., 1992). Therefore, while investigating the individual differences in risk-taking preference, it is important to investigate these associations separately for each gender.

Considering the literature summarized above, it is clear that risk-taking preference is influenced by demographic factors and psychological traits. It is also well-established that understanding these relationships in undergraduate populations is particularly important, due to the various developmental and life transitions they experience. Previous studies examining these associations either utilized a limited number of demographic factors and psychological traits (e.g. Big-Five personality traits only), or utilized a variety of risk-taking measures (i.e. from more dynamic ones to more stable ones). Therefore, in this study, the associations between multiple psychological traits related to risk-taking are considered together with Dohmen's general risk question. By considering the influence of gender on both psychological traits and risk-taking, and 
by testing the associations separately for men and women, this study contributes to the literature on individual differences in risk-taking preference.

\section{Aims and Hypotheses}

The aim of this study is to explore the associations between self-reported risk-taking preference and demographic factors (age, gender, personal income, parental education), Big Five personality traits, trait anxiety, self-esteem and life satisfaction. For demographic factors, higher risk taking is expected with increased age and personal income, and in men. For the Big Five personality traits, it is hypothesized that higher risk-taking will be associated with higher extraversion and openness, and lower neuroticism, agreeableness and conscientiousness. Higher risk-taking is further expected with lower trait anxiety, and higher self-esteem and life satisfaction. Considering previous research, stronger correlations of risk-taking behavior with neuroticism and trait anxiety are expected in women compared to men, and with self-esteem and extraversion in men compared to women. Investigating the associations between these factors together will contribute to our understanding of the individual differences in risk-taking preference of emerging adults. The results of this initial study will also be important in guiding ongoing research on understanding individual differences across multiple risk-taking domains.

\section{Method}

Participants were 177 undergraduate students aged 18 to $29\left(M_{\text {age }}=20.62, S D_{\text {age }}=1.80 ; 42 \%\right.$ Female) from Bogazici University, Istanbul, Turkey. Participants were recruited through flyers posted on the Psychology Department's bulletin board and compensated by course credits. Demographic factors, such as age, gender, parental education and source and amount of personal income were collected by self-reports. Source of income was categorized as family, work, scholarship, and other. Amount of personal income was assessed in Turkish Liras with the following categories: 0-250, 251-500, 501-750, 751-1000, 1001-1500, 1501-2000, 2001 or higher. Bogazici University is located in a major city and admits students from different regions of Turkey, with a variety of demographic, socioeconomic and psychosocial characteristics that influence risktaking behavior. Therefore, the participants are expected to represent the general undergraduate population in Turkey.

Risk-taking preference was measured by Dohmen's general risk question, a single-item self-report measure of general risk-taking preference: "How much are you generally willing to take risks?" It is answered from 0: Not at all to 10: Very much. This measure is shown to be a good predictor of general risk-taking preference and has been widely used in research related to psychological traits (Dohmen et al., 2011; Gurdal et al., 2017). Big Five personality traits were measured by the Big Five Inventory (BFI; Benet-Martinez \& John, 1998; John et al., 1991), which is a 44-item scale with subscales of extraversion, agreeableness, conscientiousness, neuroticism, and openness. The inventory includes items such as "I see myself as someone who does a thorough job" and "I see myself as someone who gets nervous easily," rated from 1: Disagree strongly to 5: Agree strongly. For the extraversion and neuroticism subscales, the scores range from 8 to 40 . For openness subscale, they range from 10 to 50, and for the remaining subscales, they range from 9 to 45. Higher scores indicate higher levels of the corresponding personality trait. The Turkish translation of the inventory is commonly used (Sümer et al., 2005). The Cronbach alpha coefficients of subscales for this study are between .70 and .82 . 
Self-esteem was measured from the Rosenberg Self-Esteem Scale, which consists of 5 positively and 5 negatively phrased items rated from 0: Very wrong to 3: Very right (Rosenberg, 1965). Total scores change from 0 to 30 and higher scores indicate higher self-esteem. The Turkish translation is commonly used in undergraduate populations and is reliable and valid (Çuhadaroğlu, 1986). The Cronbach alpha coefficient for this study is .88 .

Life satisfaction was measured by the Satisfaction with Life Scale (Diener et al., 1985), which consists of 5 items like "In most ways my life is close to my ideal," rated from 1: Strongly disagree to 7: Strongly agree. Total scores range from 5 to 35 with higher scores indicating higher life satisfaction. The Turkish translation is commonly used in undergraduate populations and has good psychometric properties (Durak et al., 2010). The Cronbach alpha coefficient for this study is .83.

Trait anxiety was measured by the State Trait Anxiety Inventory X (STAI-X) - Trait form (Spielberger et al., 1970), which is a 20-item inventory that assesses trait anxiety symptoms, such as "I feel secure" and "I avoid to be in difficult situations". Items are rated on a 4-point Likert scale from 1: Almost never to 4: Almost always. Total scores range from 20 to 80 and higher scores indicate higher trait anxiety. The Turkish version is commonly used as a trait anxiety measure and has good psychometric properties (Öner \& Le Compte, 1985). The Cronbach alpha coefficient for this study is .90 .

The study was part of a larger study and all procedures were approved by the Bogazici University Human Research Ethics Committee. Participants were invited to a computer lab where they were informed about the study. They provided oral and written consents. Afterwards, they completed the questionnaires. Following the end of the sessions, debriefing forms were emailed to all participants.

All data analysis was conducted in SPSS version 25. Participants' characteristics were indicated as means, frequencies, and percentages. Gender differences were tested by $t$-test or chisquare analyses. The relationships between risk-taking and demographic and psychological traits were investigated by $t$-tests and Pearson correlations. The power analysis indicated that for a small effect, 177 participants provided $85 \%$ power. For all analyses, alpha is taken as 0.05 .

\section{Results}

Participants' demographic characteristics, such as gender, parental education and source and amount of personal income, are shown in Table 1. As seen from the frequency distribution of the demographic characteristics, there is variety among the participants' socioeconomic characteristics. Participants' fathers were significantly more educated than their mothers $(p<.05)$. The most frequent source of personal income was from family and scholarship and was between 501-750 TL. There were no significant differences in age, maternal and paternal education by gender. For women, income from family was significantly more common than men $(p<.05)$. Women also had lower personal income than men, such that having 251-500 TL income was significantly more frequent and having 1001 and higher income was significantly less frequent than men $(p<.05)$. Personal income was significantly correlated with both paternal $(r=.31, p<$ $.001)$ and maternal $(r=.28, p<.001)$ education, similarly for men and women. 
Table 1

\begin{tabular}{|c|c|c|}
\hline Demographics & $n$ & $\%$ \\
\hline Gender & 177 & \\
\hline Women & 74 & $\% 41.8$ \\
\hline Men & 103 & $\% 58.2$ \\
\hline Maternal education & 177 & \\
\hline Primary school or lower & 49 & $\% 27.7$ \\
\hline Middle to high school & 64 & $\% 36.1$ \\
\hline Undergraduate or higher & 64 & $\% 36.2$ \\
\hline Paternal education & 177 & \\
\hline Primary school or lower & 16 & $\% 9$ \\
\hline Middle to high school & 61 & $\% 34.5$ \\
\hline Undergraduate or higher & 100 & $\% 56.5$ \\
\hline Source of personal income & 177 & \\
\hline Family & 59 & $\% 33.3$ \\
\hline Scholarship & 17 & $\% 9.6$ \\
\hline Work & 1 & $\% 0.6$ \\
\hline Family and scholarship & 65 & $\% 36.7$ \\
\hline Family and work & 11 & $\% 6.2$ \\
\hline Scholarship and work & 9 & $\% 5.1$ \\
\hline Family, scholarship and work & 15 & $\% 8.5$ \\
\hline Personal income ${ }^{a}$ & 174 & \\
\hline $0-250$ & 9 & $\% 5.2$ \\
\hline $251-500$ & 33 & $\% 19$ \\
\hline $501-750$ & 41 & $\% 23.6$ \\
\hline $751-1000$ & 32 & $\% 18.4$ \\
\hline $1001-1500$ & 30 & $\% 17.2$ \\
\hline $1501-2000$ & 17 & $\% 9.8$ \\
\hline 2001 and higher & 12 & $\% 6.9$ \\
\hline
\end{tabular}

Table 2 Descriptive statistics of participants' risk-taking preference and psychological traits by gender

\begin{tabular}{|c|c|c|c|c|c|c|c|}
\hline \multirow[t]{2}{*}{ Characteristic } & \multicolumn{2}{|c|}{ Women } & \multicolumn{4}{|c|}{ Men } & \multirow[b]{2}{*}{$p$} \\
\hline & $M$ & $S D$ & Range & $M$ & $S D$ & Range & \\
\hline Risk-taking preference & 4.88 & 2.16 & $0-10$ & 5.76 & 1.97 & $0-10$ & $* *$ \\
\hline \multicolumn{8}{|l|}{ BFI Personality traits ${ }^{\mathrm{a}}$} \\
\hline Extraversion & 24.82 & 5.12 & $11-39$ & 25.07 & 5.92 & $8-38$ & \\
\hline Aggreeableness & 31.50 & 4.21 & $23-42$ & 30.41 & 5.27 & $15-45$ & \\
\hline Conscientiousness & 31.19 & 4.93 & $18-45$ & 30.71 & 5.71 & $17-43$ & \\
\hline Neuroticism & 25.59 & 4.71 & $15-37$ & 22.97 & 6.59 & $9-36$ & $* *$ \\
\hline Openness & 37.36 & 5.72 & $20-49$ & 37.86 & 6.39 & $21-50$ & \\
\hline Life satisfaction ${ }^{\mathrm{b}}$ & 22.77 & 5.22 & $5-31$ & 22.42 & 6.05 & $7-31$ & \\
\hline Self-esteem ${ }^{c}$ & 19.04 & 4.41 & $10-29$ & 19.85 & 5.60 & $5-30$ & \\
\hline Trait anxiety $^{\mathrm{d}}$ & 47.53 & 7.78 & $32-69$ & 43.34 & 8.94 & $25-66$ & $* * *$ \\
\hline
\end{tabular}


Participants' descriptive statistics for risk-taking preference and psychological traits by gender are summarized in Table 2. For all measures, there were participants covering the range of the scales. As hypothesized, women reported significantly lower risk-taking preference than men $(t(175)=2.81, p<.01)$. Women also reported significantly higher neuroticism $(t(175)=-3.09, p$ $<.01)$ and trait anxiety $(t(175)=-3.24, p<.001)$ than men.

The correlations between risk-taking preference and psychological trait measures are summarized in Table 3. Among the Big Five personality traits, extraversion was significantly and negatively correlated with neuroticism and positively correlated with openness. Conscientiousness was significantly and negatively correlated with neuroticism and positively correlated at a trend level with agreeableness. In addition to these personality traits, there were significant correlations considering the measures of life satisfaction, self-esteem, and trait anxiety. As life satisfaction increased, self-esteem, extraversion, agreeableness, and conscientiousness significantly increased, whereas neuroticism and trait anxiety significantly decreased. Self-esteem significantly and positively correlated with extraversion, conscientiousness, and life satisfaction, and negatively correlated with neuroticism and trait anxiety. Trait anxiety was significantly and positively correlated with neuroticism, and negatively correlated with extraversion, life satisfaction, and selfesteem. As the personal income of participants increased, extraversion $(r=.15, p<.05)$, openness $(r=.19, p<.05)$, and self-esteem $(r=.26, p<.001)$ increased, while neuroticism $(r=-.16, p<$ $.05)$ and trait anxiety $(r=-.23, p<.01)$ decreased. Age was not significantly associated with any of the psychological traits.

Table 3

Correlations between risk-taking preference and psychological traits

\begin{tabular}{|c|c|c|c|c|c|c|c|c|c|}
\hline Variable & 1 & 2 & 3 & 4 & 5 & 6 & 7 & 8 & 9 \\
\hline 1.Risk-taking preference & - & & & & & & & & \\
\hline 2. Extraversion & $.32^{* * *}$ & - & & & & & & & \\
\hline 3. Agreeableness & $.18^{*}$ & .12 & - & & & & & & \\
\hline 4. Conscientiousness & -.06 & .12 & $.13^{\dagger}$ & - & & & & & \\
\hline 5. Neuroticism & $-.18^{*}$ & $-.24^{* *}$ & -.12 & $-.20^{* *}$ & - & & & & \\
\hline 6. Openness & $.20^{* *}$ & $.21^{* *}$ & .06 & .01 & .12 & - & & & \\
\hline 7. Life satisfaction & .09 & $.20^{* *}$ & $.19^{*}$ & $.25^{* * *}$ & $-.20^{* *}$ & -.07 & - & & \\
\hline 8. Self-esteem & $.28^{* * *}$ & $.27^{* * *}$ & .08 & $.27^{* * * *}$ & $-.42^{* * * *}$ & .07 & $.51^{* * *}$ & - & \\
\hline 9. Trait anxiety & $-.30^{* * *}$ & $-.29^{* * *}$ & -.10 & -.05 & $.69^{* * *}$ & .04 & $-.40^{* * * *}$ & $-.64^{* * * *}$ & - \\
\hline
\end{tabular}

When associations with risk-taking preference were investigated, risk-taking was shown to be significantly correlated with multiple demographic factors and psychological traits (Table 3). As age increased, risk-taking significantly increased $(r=.17, p<.05)$, primarily driven by women $(r=.23, p<.05)$ but not men $(r=.14, p>.05)$. However, when scatterplots were observed, it was seen that the 29-year old male participant as an outlier for age may influence this association. Without this participant, men also showed a significant correlation with age $(r=.23, p<.05)$. Personal income was significantly and positively correlated with risk-taking preference $(r=.18, p$ $<.05)$, suggesting higher risk-taking preference with higher personal income. Parental education was not significantly associated with risk-taking.

Risk-taking preference was significantly increased by higher extraversion $(r=.32, p<$ $.001)$, agreeableness $(r=.18, p<.05)$, openness $(r=.20, p<.01)$, and self-esteem $(r=.28, p<$ 
$.001)$. On the other hand, it was significantly decreased with higher neuroticism $(r=-.18, p<.05)$ and trait anxiety $(r=-.30, p<.001)$.

When the correlations were investigated by gender, there were some significant differences among men and women (Table 4). The relationship of conscientiousness $(r=-.35, p<.01)$ and neuroticism $(r=-.27, p<.05)$ with risk-taking was only significant for women, but not for men $(r \mathrm{~s}<.1, p>.05)$. For trait anxiety, women exhibited a stronger correlation with risk-taking preference $(r=-.31, p<.01)$ than men $(r=-.24, p<.05)$. In contrast, the relationship of openness $(r=.27, p<.01)$, agreeableness $(r=.22, p<.05)$, self-esteem $(r=.35, p<.001)$ and life satisfaction $(r=.24, p<.05)$ with risk-taking was only significant for men, but not for women $(p>.05)$. For extraversion $(r=.36, p<.001)$, men had a stronger correlation with risk-taking preference than women $(r=.27, p<.05)$.

Table 4 Correlations between risk-taking preference and psychological traits by gender

\begin{tabular}{lccc}
\hline & Women & Men & Total \\
\hline Variable & & & \\
\hline 1. Risk-taking preference & - & - & - \\
2. Extraversion & $.27^{*}$ & $.36^{* * *}$ & $.32^{* * *}$ \\
3. Agreeableness & .19 & $.22^{*}$ & $.18^{*}$ \\
4. Conscientiousness & $-.35^{* *}$ & .14 & -.06 \\
5. Neuroticism & $-.27^{*}$ & -.08 & $-.18^{*}$ \\
6. Openness & .09 & $.27^{* *}$ & $.20^{* *}$ \\
7. Life satisfaction & -.10 & $.24^{*}$ & .09 \\
8. Self-esteem & .15 & $.35^{* * *}$ & $.28^{* * *}$ \\
9. Trait anxiety & $-.31^{* *}$ & $-.24^{*}$ & $-.30^{* * *}$ \\
\hline Note. ${ }^{\dagger} p<.1,{ }^{*} p<.05,{ }^{* *} p<.01,{ }^{* * * *} p<.001$. & &
\end{tabular}

\section{Discussion}

The study results identified modest but significant relationships between risk-taking preference, demographic factors, and psychological traits in emerging adults. As expected, men exhibited higher risk-taking preference, and as age and personal income increased, risk-taking preference increased. These findings are in line with previous research (e.g. Schurer, 2015), including those from Turkey (reviewed in Ones, 2019; Gurdal et al., 2017; Ozkan \& Oztemel, 2018). The gender difference is attributed to many theories in the field; one theory, for example, speculates that whereas men view risk as a challenge to overcome, women view it more as a threat (Croson \& Gneezy, 2009). In terms of age, the findings suggest increased risk-taking with increased age, similar to previously reported findings for young adults (Josef et al., 2016). This increased risktaking by age may also be related to personal income as supported by positive associations between the two. Similarly, while parental education was not associated with risk-taking, it was positively associated with personal income, suggesting a potential influence on risk-taking together with personal income (Grable, 2000). These results suggest higher risk-taking preference in undergraduates who are males, older, and have higher personal income.

In terms of the relationships between risk-taking and psychological traits, there were weak to moderate but significant associations, some of which varied by gender. Among the Big Five 
traits, higher risk-taking preference was associated with higher extraversion and openness and lower neuroticism as expected. These findings are in line with previous studies reporting associations with risk-taking preference, risk tolerance and investment decisions (Hitay \& Anbar, 2020; Josef et al., 2016; Koyluoglu et al., 2019; Nicholson et al., 2005; Oehler et al., 2018; Pan \& Statman, 2013; Pinjisakikool, 2017) but conflict with others (Filbeck et al., 2005; Prinz et al., 2014). Extraversion and neuroticism showed stronger correlations with risk-taking in men and women, respectively. Agreeableness was weakly but positively associated with risk-taking, driven mostly by men, a finding opposed to our hypothesis but in line with other studies, that suggest its relevance to thrill seeking behavior in early age (Koyluoglu et al., 2019; Prinz et al., 2014). On the other hand, higher conscientiousness was associated with lower risk-taking in women but not in men (Baffour et al., 2018). Risk-taking preference also increased as self-esteem increased and trait anxiety decreased, confirming our hypothesis and supporting previous research (Giorgetta et al., 2012; Khosravi et al., 2016). However, life satisfaction and risk-taking were significantly related only in men. The influence of self-esteem was stronger for men, while trait anxiety was stronger for women, supporting studies investigating gender differences in risky behavior in relation to selfesteem (Rosenthal et al., 1991; Tian et al., 2019). These differences may be particularly important for establishing gender roles and social influences, especially in countries like Turkey (Ongen, 2007). On the contrary, trait anxiety was both higher in women and more strongly associated with risk-taking in women than men, in line with studies reporting gender differences in relation to trait anxiety and decision-making (de Visser et al., 2010). These results indicate that risk-taking behavior is significantly influenced by demographic factors and psychological traits, reflecting the importance of genetic and psychosocial factors on behavior. Furthermore, considering the assessment of risk-taking by a single self-report question, this study also supports the validity of the use of this assessment in research as an efficient measure (Dohmen et al., 2011; Gurdal et al., 2017).

Some of the associations of demographic factors and psychological traits with risk-taking were stronger than others and differed by gender, such as neuroticism and anxiety (Gambetti \& Giusberti, 2012; Soane \& Chmiel, 2005). These are also traits that exhibit higher heritability and prominent gender differences that further influence intermediate phenotypes (endophenotypes) of risk-taking, such as changes in neural pathways related to fear, anxiety and decision-making (Huo et al., 2020; Studer et al., 2013; Visser et al., 2010). Therefore, future studies investigating these associations may benefit from taking these kinds of endophenotypes into account through brain imaging and other physiological measures. This would also allow us to test the effects of individuals' physiology on risk-taking. For instance, an increasing number of studies suggest that the physiological state of individuals, such as the activation of stress response systems (e.g. cortisol hormone levels), dynamically influence risk-taking behavior (Kandasamy et al., 2014; van den Bos et al., 2014). Further investigating these endophenotypes would thus improve both our understanding of the underlying biological processes related to risk-taking and their influences on it.

Considering the findings of this study, future studies would benefit from considering gender and psychological traits while measuring risk-taking. However, our findings are based on a single general risk question in a limited number of emerging adults. Although the validity of this item is well-established in the literature (Dohmen et al., 2011) and in Turkey in particular (Gurdal et al., 2017), including a combination of self-report and behavioral risk-taking in a larger population would allow us to understand the contribution of individual differences to varying domains of risk-taking (Dohmen et al., 2011; Nicholson et al., 2005). Previous studies have shown 
that self-report measures of risk preference, such as the general risk question used in this study, reliably represent the stable component of risk preference and possess similarities with the constructs of psychological traits (Dohmen et al., 2011; Frey et al., 2017; Gurdal et al., 2017). However, focusing on this general and more stable component limits our ability to capture the more dynamic components of risk-taking. For instance, considering previous research, there is evidence that responses to self-reports and behavioral paradigms may differ, as well as the stability of these responses over time. Furthermore, depending on the characteristics and outcomes of paradigms, individuals' risk preference may change. In particular, multiple studies over time emphasized that factors such as the amount of incentives, whether the situation is real or hypothetical, the variability of risk, the consequences of the outcome, and the conditions under which the assessment is performed may influence risk preference (Dohmen et al., 2011; Holt \& Laury, 2002; Mata et al., 2018; Schildberg-Horisch, 2018). Therefore, future studies investigating the relation of risk preference to demographic factors and psychological traits would benefit from using paradigms that address these characteristics. In terms of the participant population, while Bogazici University is broadly representative of the undergraduate population in Turkey, considering its location and high rank among universities in Turkey, it may also have students with different psychological traits and risk exposure. Therefore, testing the same effects in emerging adult populations across different universities in Turkey would mitigate this possibly distorting effect. Due to the known genetic influences on psychological traits, considering genetic factors related to risk-taking (Kuhnen \& Chiao, 2009), such as those of dopaminergic and serotonergic systems, would also complement the results of this study. Finally, several studies on risk-taking suggest the importance of contextual and social factors on individuals' preferences. For instance, the risk-taking behavior of individuals changes when they are in groups, as well as during active risk-taking situations (e.g. gambling, investing) (Bourgheas et al., 2013; Ozorio \& Fong, 2004). In this study, the participants' risk-taking preference was measured during a computer lab session. By conducting the sessions in the same setting, we controlled for some contextual influences. However, findings from studies that investigate risk-taking in different contexts (e.g. during the COVID-19 pandemic) and in real life situations (e.g. Gurdal et al., 2017) would enhance our understanding of changes in risk-taking preference.

This study is important in demonstrating the individual demographic and psychological trait differences related to general risk-taking preference in undergraduate students. Considering the associations between risky behavior and mental health (Hallfors et al., 2005; Mishra et al., 2010; Waller et al., 2006), the results contribute to identifying moderating factors (e.g. gender, personality) that influence these associations. This would allow both identifying populations at risk for mental health problems, as well as develop prevention and intervention programs. 


\section{References}

Benet-Martínez, Verónica, and Oliver P. John. 1998. "Los Cinco Grandes across Cultures and Ethnic Groups: Multitrait-Multimethod Analyses of the Big Five in Spanish and English." Journal of Personality and Social Psychology 75, no. 3 (September): 729-50. doi:10.1037/0022-3514.75.3.729.

Bougheas, Spiros, Jeroen Nieboer, and Martin Sefton. 2013. "Risk-Taking in Social Settings: Group and Peer Effects." Journal of Economic Behavior and Organization 92 (August): 273-83. doi:10.1016/j.jebo.2013.06.010.

Byrnes, James P., David C. Miller, and William D. Schafer. 1999. "Gender Differences in Risk Taking: A Meta-Analysis.” Psychological Bulletin 125, no. 3 (May): 367-83. doi:10.1037/0033-2909.125.3.367.

Charpentier, Caroline J., Jessica Aylward, Jonathan P. Roiser, and Oliver J. Robinson. 2017. "Enhanced Risk Aversion, But Not Loss Aversion, in Unmedicated Pathological Anxiety." Biological Psychiatry 81, no. 12 (June): 1014-22. doi:10.1016/j.biopsych.2016.12.010.

Costa, Paul T., Antonio Terracciano, and Robert R. McCrae. 2001. "Gender Differences in Personality Traits across Cultures: Robust and Surprising Findings.” Journal of Personality and Social Psychology 81, no. 2 (August): 322-31. doi:10.1037/0022-3514.81.2.322.

Costa Jr., Paul T., and Robert R. McCrae. 2008. "The Revised NEO Personality Inventory (NEOPI-R).” In the SAGE Handbook of Personality Theory and Assessment, Vol. 2. Personality Measurement and Testing, edited by Boyle, Gregory J., Gerald Matthews, and Donald H. Saklofske, 179-98. California: Sage Publications, Inc.

Croson, Rachel, and Uri Gneezy. 2009. “Gender Differences in Preferences.” Journal of Economic Literature 47, no. 2 (June): 448-74. doi:10.1257/jel.47.2.448.

Cuhadaroglu, Fusun. 1986. “Adolesanlarda Benlik Saygısı (Self Esteem in Adolescents).” PhD diss., Hacettepe University.

de Visser, Leonie, Lisette J. van der Knaap, Aurora J.A.E. van de Loo, C.M.M. van der Weerd, Frauke Ohl, and Ruud van den Bos. 2010. "Trait Anxiety Affects Decision-Making Differently in Healthy Men and Women: Towards Gender-Specific Endophenotypes of Anxiety." Neuropsychologia 48, no. 6 (May): 1598-1606. doi:10.1016/j.neuropsychologia.2010.01.027.

Demaree, Heath A., Michael A. DeDonno, Kevin J. Burns, and D. Erik Everhart. 2008. "You Bet: How Personality Differences Affect Risk-Taking Preferences." Personality and Individual Differences 44, no. 7 (May): 1484-94. doi:10.1016/j.paid.2008.01.005.

Diener, Ed, Robert A. Emmons, Randy J. Larsen, and Sharon Griffin. 1985. "The Satisfaction with Life Scale." Journal of Personality Assessment 49, no. 1 (June): 71-75. https://doi.org/10.1207/s15327752jpa4901_13.

Dohmen, Thomas, Armin Falk, David Huffman, Uwe Sunde, Jürgen Schupp, and Gert G. Wagner. 2011. "Individual Risk Attitudes: Measurement, Determinants, and Behavioral Consequences." Journal of the European Economic Association 9, no. 3 (June): 522-550. https://doi.org/10.1111/j.1542-4774.2011.01015.x. 
Duman, Elif A., and Turhan Canli. 2010. "Molecular Psychology of Personality." In Encyclopedia of Behavioral Neuroscience, edited by Koob, George F., Michel Le Moal, and Richard F. Thompson, 257-60. London: Elsevier.

Durak, Mithat, Emre Senol-Durak, and Tulin Gencoz. 2010. "Psychometric Properties of the Satisfaction with Life Scale among Turkish University Students, Correctional Officers, and Elderly Adults." Social Indicators Research 99, no. 3, (February): 413-429. doi:10.1007/s11205-010-9589-4.

Figner, Bernd, and Elke U. Weber. 2011. "Who Takes Risks When and Why? Determinants of Risk Taking." Current Directions in Psychological Science 20, no. 4 (August): 211-16. https://doi.org/10.1177/0963721411415790.

Filbeck, Greg, Patricia Hatfield, and Philip Horvath. 2005. "Risk Aversion and Personality Type." Journal of Behavioral Finance 6, no. 4 (June): 170-80. https://doi.org/10.1207/s15427579jpfm0604_1.

Frey, Renato, Andreas Pedroni, Rui Mata, Jörg Rieskamp, and Ralph Hertwig. 2017. "Risk Preference Shares the Psychometric Structure of Major Psychological Traits." Science Advances 3, no. 10 (October). e1701381. doi:10.1126/sciadv.1701381.

Gambetti, Elisa, and Fiorella Giusberti. 2012. "The Effect of Anger and Anxiety Traits on Investment Decisions." Journal of Economic Psychology 33, no. 6 (December): 1059-69. https://doi.org/10.1016/j.joep.2012.07.001.

Gardner, Margo, and Laurence Steinberg. 2005. "Peer Influence on Risk Taking, Risk Preference, and Risky Decision Making in Adolescence and Adulthood: An Experimental Study." Developmental Psychology 41, no. 4 (July): 625-35. doi:10.1037/0012-1649.41.4.625.

Giorgetta, Cinzia, Alessandro Grecucci, Sophia Zuanon, Laura Perini, Matteo Balestrieri, Nicolao Bonini, Alan G. Sanfey, and Paolo Brambilla. 2012. "Reduced Risk-Taking Behavior as a Trait Feature of Anxiety." Emotion 12, no. 6 (December): 1373-83. doi:10.1037/a0029119.

Grable, John E. 2000. "Financial Risk Tolerance and Additional Factors That Affect Risk Taking in Everyday Money Matters.” Journal of Business and Psychology 14, no. 4 (June): 62530. https://doi.org/10.1023/A:1022994314982.

Gurdal, Mehmet Y., Tolga U. Kuzubas, and Burak Saltoglu. 2017. "Measures of Individual Risk Attitudes and Portfolio Choice: Evidence from Pension Participants." Journal of Economic Psychology 62 (October): 186-203. https://doi.org/10.1016/j.joep.2017.06.010.

Hallfors, Denise D., Martha W. Waller, Daniel Bauer, Carol A. Ford, and Carolyn T. Halpern. 2005. "Which Comes First in Adolescence-Sex and Drugs or Depression?" American Journal of Preventive Medicine 29, no. 3 (October): 163-170. https://doi.org/10.1016/j.amepre.2005.06.002.

Hitay, Kezban, and Adem Anbar. 2020. "Kişilik Özelliklerinin Finansal Risk Toleransı üzerindeki Etkisi: Üniversite Öğrencileri üzerine bir Araştırma (The Effect of Personality Traits on Financial Risk Tolerance: An Investigation on University Students)." Muhasebe ve Finansman Dergisi 87 (July): 203-24. doi:10.25095/mufad.756296.

Holt, Charles A., and Susan K. Laury. "Risk aversion and incentive effects." American Economic Review 92, no. 5 (2002): 1644-1655. 
Howlett, Jonathon R., and Martin P. Paulus. 2017. "Individual Differences in Subjective Utility and Risk Preferences: The Influence of Hedonic Capacity and Trait Anxiety." Frontiers in Psychiatry 8, (May): 88. https://doi.org/10.3389/fpsyt.2017.00088.

Huo, Hangfeng, Rong Zhang, Carol A. Seger, Tingyong Feng, and Qi Chen. 2020. "The Effect of Trait Anxiety on Risk-Taking: Functional Coupling between Right Hippocampus and Left Insula.” Psychophysiology 57, no. 10 (July). e13629. doi:10.1111/psyp.13629.

Jianakoplos, Nancy Ammon, and Alexandra Bernasek. 2006. "Financial Risk Taking by Age and Birth Cohort." Southern Economic Journal 72, no. 4 (April): 981-1001. doi: $10.2307 / 20111864$.

John, Oliver P., Eileen M. Donahue, and Robert L. Kentle. 1991. Big Five Inventory--Versions 4a and 54. Berkeley, CA: University of California, Berkeley, Institute of Personality and Social Research.

Josef, Anika K., David Richter, Gregory R. Samanez-Larkin, Gert G. Wagner, Ralph Hertwig, and Rui Mata. 2016. "Stability and Change in Risk-Taking Propensity across the Adult Life Span.” Journal of Personality and Social Psychology 111, no. 3 (January): 430-50. http://dx.doi.org/10.1037/pspp0000090.

Josephs, Robert A., Hazel R. Markus, and Romin W. Tafarodi. 1992. "Gender and Self-Esteem." Journal of Personality and Social Psychology 63, no. 3 (September): 391-402. https://doi.org/10.1037/0022-3514.63.3.391.

Kalabalik, Yunus, and S. Aren. 2018. "The Effects of Demographic Factors on the Relationship between Personality Traits and Financial Risk Taking." In International Congress of Management, Economy and Policy-2018 Spring Proceedings Book, Istanbul, Turkiye, 256-67.

Kandasamy, Narayanan, Ben Hardy, Lionel Page, Markus Schaffner, Johann Graggaber, Andrew S. Powlson, Paul C. Fletcher, Mark Gurnell, and John Coates. 2014. "Cortisol Shifts Financial Risk Preferences." Proceedings of the National Academy of Sciences 111, no. 9 (March): 3608-13. https://doi.org/10.1073/pnas.1317908111.

Khosravi, Ahmad, Asghar Mohammadpoorasl, Kourosh Holakouie-Naieni, Mahmood Mahmoodi, Ali Akbar Pouyan, and Mohammad Ali Mansournia. 2016. "Causal Effect of Self-Esteem on Cigarette Smoking Stages in Adolescents: Coarsened Exact Matching in a Longitudinal Study." Osong Public Health and Research Perspectives 7, no. 6 (December): 341-45. doi:10.1016/j.phrp.2016.10.003.

Koyluoglu, Selcuk, Mesut A. Dogan, and Abdurrahman Gumrah. 2019. "Tüketicilerin Kişilik Özellikleri ile Finansal İyilik Hâli ve Risk Alma Tutumu Arasındaki İlişki. (The Relationship between Personality Characteristics of Consumers with Financial Well-Being and Risk-Taking Attitude)" Selçuk Üniversitesi Sosyal Bilimler Meslek Yüksekokulu Dergisi 22, no. 2 (November): 903-13. https://doi.org/10.29249/selcuksbmyd.634842.

Kuhnen, Camelia M., and Joan Y. Chiao. 2009. "Genetic Determinants of Financial Risk Taking." PloS one 4, no. 2 (February): e4362. https://doi.org/10.1371/journal.pone.0004362. 
MacDonald, John M., Alex R. Piquero, Robert F. Valois, and Keith J. Zullig. 2005. "The Relationship between Life Satisfaction, Risk-Taking Behaviors, and Youth Violence." Journal of Interpersonal Violence 20, no. 11 (November): 1495-518. https://doi.org/10.1177/0886260505278718.

Mamerow, Loreen, Renato Frey, and Rui Mata. 2016. "Risk Taking across the Life Span: A Comparison of Self-Report and Behavioral Measures of Risk Taking." Psychology and Aging 31, no. 7 (November): 711-23. https://doi.org/10.1037/pag0000124.

Mata, Rui, Renato Frey, David Richter, Jürgen Schupp, and Ralph Hertwig. 2018. "Risk preference: A view from psychology." Journal of Economic Perspectives 32, no. 2: 15572.

Mishra, Sandeep, Martin L. Lalumière, and Robert J. Williams. 2010. "Gambling as a Form of Risk-Taking: Individual Differences in Personality, Behavioral Preferences for Risk, and Risk-Accepting Attitudes." Personality and Individual Differences 49, no. 6 (October): 616-21. https://doi.org/10.1016/j.paid.2010.05.032.

Nicholson, Nigel, Emma Soane, Mark Fenton-O'Creevy, and Paul Willman. 2005. "Personality and Domain-Specific Risk Taking.” Journal of Risk Research 8, no. 2 (March): 157-76. https://doi.org/10.1080/1366987032000123856.

Oehler, Andreas, and Florian Wedlich. 2018. "The Relationship of Extraversion and Neuroticism with Risk Attitude, Risk Perception, and Return Expectations.” Journal of Neuroscience, Psychology, and Economics 11, no. 2 (June): 63-92. https://doi.org/10.1037/npe0000088.

Oner, Necla, and William A. LeCompte. 1983. Durumluk-Sürekli Kayg1 Envanteri El Kitabı (State-Trait Anxiety Inventory Handbook). Istanbul: Boğaziçi Üniversitesi Yayınları.

Ones, Umut. 2019. "Davranışsal İktisat Deneylerinde Toplumsal Cinsiyet Temelli Farklar (Gender Differences in Behavioral Economics Experiments).” Mülkiye Dergisi 43, no. 2 (June): 411-34.

Ongen, Demet Erol. 2007. “The Relationships between Sensation Seeking and Gender Role Orientations among Turkish University Students." Sex Roles 57, no. 1-2 (May): 111-18. doi:10.1007/s11199-007-9214-4.

Ozkan, Murat Sinan, and Kemal Oztemel. 2018. “Üniversite Öğrencilerinin Risk Alma Tutumlar1 ile Kimlik Statüleri ve Bazı Demografik Değişkenler arasındaki İlişkilerin İncelenmesi (Examination of the Relationships between University Student's Risk Taking Attitudes, Identity Status and Some Demographic Variables)." Bartın Üniversitesi Eğitim Araştırmaları Dergisi 2, no. 1 (June): 1-25.

Ozorio, Bernadete, and Davis Ka-Chio Fong. 2004. "Chinese Casino Gambling Behaviors: Risk Taking in Casinos vs. Abstract Investments.” UNLV Gaming Research \& Review Journal 8, no. 2 (December): 27-38.

Pan, Carrie H., and Meir Statman. 2013. “Investor Personality in Investor Questionnaires.” Journal of Investment Consulting 14, no. 1 (May): 48-56. https://ssrn.com/abstract=2235347.

Pharo, Henry, Clark Sim, Mikala Graham, Julien Gross, and Harlene Hayne. "Risky business: executive function, personality, and reckless behavior during adolescence and emerging adulthood." Behavioral neuroscience 125, no. 6 (2011): 970. 
Pinjisakikool, Teerapong. 2017. “The Effect of Personality Traits on Households' Financial Literacy." Citizenship, Social and Economics Education 16, no. 1 (February): 39-51. https://doi.org/10.1177/2047173417690005.

Rosenberg, Morris. 1965. Society and the Adolescent Self-Image. Princeton, NJ: Princeton University Press.

Rosenthal, Doreen, Susan Moore, and Irene Flynn. 1991. “Adolescent Self-Efficacy, Self-Esteem and Sexual Risk-Taking." Journal of Community and Applied Social Psychology 1, no. 2 (June): 77-88. https://doi.org/10.1002/casp.2450010203.

Prinz, Susanne, Gerhard Gründer, Ralf Dieter Hilgers, Oliver Holtemöller, and Ingo Vernaleken. 2014. "Impact of Personal Economic Environment and Personality Factors on Individual Financial Decision Making." Frontiers in Psychology 5 (March): 158. https://doi.org/10.3389/fpsyg.2014.00158.

Savi-Cakar, Firdevs, and Ozlem Tagay. 2017. "The Mediating Role of Self-Esteem: The Effects of Social Support and Subjective Well-Being on Adolescents' Risky Behaviors." Educational Sciences: Theory and Practice 17, no. 3 (April): 859-76. https://doi.org/10.12738/estp.2017.3.0024.

Savi-Cakar, Firdevs, Ozlem Tagay, and Zeynep Karatas. 2015. “Adolescents' Life Satisfaction: Risky Behaviors and Hopelessness." International Journal on New Trends in Education \& Their Implications 6, no. 1 (January): 55-62.

Schildberg-Hörisch, Hannah. 2018. “Are Risk Preferences Stable?." Journal of Economic Perspectives 32, no. 2 (Spring): 135-54. doi:10.1257/jep.32.2.135.

Schurer, Stefanie. 2015. "Lifecycle Patterns in The Socioeconomic Gradient of Risk Preferences." Journal of Economic Behavior \& Organization 119 (November): 482-95. https://doi.org/10.1016/j.jebo.2015.09.024.

Soane, Emma, and Nik Chmiel. 2005. "Are Risk Preferences Consistent?: The Influence of Decision Domain and Personality." Personality and Individual Differences 38, no. 8 (June): 1781-91. https://doi.org/10.1016/j.paid.2004.10.005.

Speilberger, Charles D., and Peter R. Vagg. 1984. "Psychometric Properties of the STAI: A Reply to Ramanaiah, Franzen, and Schill." Journal of Personality Assessment 48, no. 1 (February): 95-97. doi:10.1207/s15327752jpa4801_16.

Studer, Bettina, Andreas Pedroni, and Jörg Rieskamp. 2013. "Predicting Risk-Taking Behavior from Prefrontal Resting-State Activity and Personality." PLoS one 8, no. 10 (October). e76861. https://doi.org/10.1371/journal.pone.0076861.

Sümer, Nebi, Timo Lajunen, and Türker Özkan. 2005. Big Five Personality Traits as the Distal Predictors of Road Accident Involvement. Oxford: Elsevier.

Tian, Lumei, Xinyue Dong, Dayong Xia, Lu Liu, and Dawei Wang. 2019. "Effect of Peer Presence on Adolescents' Risk-Taking is Moderated by Individual Self-Esteem: An Experimental Study." International Journal of Psychology 55, no. 3 (July): 373-79. https://doi.org/10.1002/ijop.12611. 
Twumasi-Baffour, Priscilla, Ibrahim Mohammed, and Wassiuw Abdul Rahaman. 2019. "Personality and Gender Differences in Revealed Risk Preference: Evidence from Ghana." International Journal of Social Economics 46, no. 5 (May): 631-47. doi:10.1108/ijse-072018-0346.

Valois, Robert F., Keith J. Zullig, E. Scott Huebner, Sandra K. Kammermann, and J. Wanzer Drane. 2002. "Association between Life Satisfaction and Sexual Risk-Taking Behaviors among Adolescents." Journal of Child and Family Studies 11, no. 4 (December): 427-40. https://doi.org/10.1023/A:1020931324426.

Van Den Bos, Ruud, Ruben Taris, Bianca Scheppink, Lydia de Haan, and Joris Verster. 2014. "Salivary Cortisol and Alpha-Amylase Levels During an Assessment Procedure Correlate Differently with Risk-Taking Measures in Male and Female Police Recruits." Frontiers in Behavioral Neuroscience 7 (January): 219. https://doi.org/10.3389/fnbeh.2013.00219.

Waller, Martha W., Denise D. Hallfors, Carolyn J. Tucker-Halpern, Bonita J. Iritani, Carol A. Ford, and Guang Guo. 2006. "Gender Differences in Associations between Depressive Symptoms and Patterns of Substance Use and Risky Sexual Behavior among a Nationally Representative Sample of US Adolescents.” Archives of Women's Mental Health 9, no. 3 (March): 139. https://doi.org/10.1007/s00737-006-0121-4.

Weisberg, Yanna J., Colin G. DeYoung, and Jacob B. Hirsh. 2011. "Gender Differences in Personality across the Ten Aspects of the Big Five." Frontiers in Psychology 2 (August): 178. https://doi.org/10.3389/fpsyg.2011.00178.

Wild, Lauren G., Alan J. Flisher, Arvin Bhana, and Carl Lombard. 2004. "Associations among Adolescent Risk Behaviours and Self-Esteem in Six Domains." Journal of Child Psychology and Psychiatry 45, no. 8 (November): 1454-67. doi: 10.1111/j.14697610.2004.00330.x. 